\title{
Satisfaction of Learning Management System Usage in a Blended Learning Environment among Undergraduate Students
}

\author{
Samar Ghazal ${ }^{1}$, Hanan Aldowah², Irfan Umar ${ }^{3}$ \\ ${ }^{I}$ Centre for Instructional Technology and Multimedia, Universiti Sains Malaysia, Penang, Malaysia, \\ Samar_ghzl@yahoo.com \\ ${ }^{2}$ Centre for Instructional Technology and Multimedia, Universiti Sains Malaysia, Penang, Malaysia, \\ hanan_aldwoah@yahoo.com
}

${ }^{3}$ Centre for Instructional Technology and Multimedia, Universiti Sains Malaysia, Penang, Malaysia, irfan@usm.my

\begin{abstract}
Learning management system (LMS) helps higher learning institutions to manage their instructional resources and complement their traditional way of teaching. Although LMS survives via students' and instructors' use, its adoption is initiated by the students' satisfaction. Thus, the objectives of this study are to examine the level of LMS satisfaction among university students in a blended learning program and to investigate the factors that may impact their satisfaction. A quantitative research approach via a questionnaire was used in the study. The subjects consisted of undergraduate students in a public university in Yemen. A total of 174 participants were surveyed using a questionnaire. Descriptive statistics and multiple linear regression were employed. The results show that the participants have a high level of satisfaction of LMS usage in a blended learning environment. Also the findings indicated that Instructor Attitude, Classmates Attitude, Course Quality, Management Support, and System Quality are significant predictors to students' satisfaction of LMS. Therefore, this study has identified these significant factors in planning, designing and implementing a blended learning to promote and improve students' learning satisfaction.
\end{abstract}

Keywords: Blended Learning, Learning Management System, Satisfaction, Yemen

\section{Introduction}

In recent decades, the world has become as a small village because of the rapid development of Information and Communication Technology (ICT) that facilitates a concourse between technology-mediated learning environment and traditional face-to-face learning. As a result of the progress in network and communication technologies, more innovative delivery and learning solution have emerged to provide useful learning experiences for students in academic environment (Ahmed, 2010). Online courses can be in the form of traditional classroom (a face-to-face approach), blended learning (a combination of online learning and traditional approach), or pure e-learning (online learning approach) (Aldowah et al., 2015).

Blended learning has been offered as an alternative educational approach (Graham, 2006). Learning management system (LMS) is an information technology system used by educators to build, update and maintain online courses on websites. An LMS not only provides higher learning institutions with effective and efficient means to teach and train individuals, but also enables them to effectively and efficiently codify and share their knowledge. The use of LMS is becoming critical for institutions of higher learning. LMS tools enable organizations to improve their teaching and learning activities, in which a number of the best universities around the world have adopted LMS for this purposes (Jenkins et al., 2011). 
In spite of the investment and applications of ICT in these higher learning institutions, there are many indications that online courses are unsuccessful in meeting students' needs (Jenkins et al., 2011) and students are dissatisfied with their online course experiences (Lee et al., 2011). This dissatisfaction phenomenon has been at the center of an intense international debate among online educators. Researchers consistently indicate that instructors, systems, courses, and classmates are important factors contributing to the satisfaction of online courses and must to be taken into account when implementing courses online (Angelino et al., 2007). With proper attention to course content as well as an instructor and classmate interaction, the level of satisfaction with online courses could increase and meet the students' needs (Andersen, 2013) .

Students' satisfaction has been notified to be a very important factor for the successful achievement of the online course (Chang \& Fisher, 2003). While a number of features have been known in using blended learning, insufficient learning satisfaction seem to be an obstacle to the successful adoption of blended learning courses (So \& Brush, 2008). Students' satisfaction, acceptance, expectations, and attitudes play a significant role in evaluating the efficiency of the instructional process in a blended learning environment (Akkoyunlu \& Soylu, 2008). However, there are insufficient studies investigating students' satisfaction with a blended learning system used to support teaching and learning in a blended environment (Bauk et al., 2014). Therefore, this study seeks to examine the students' satisfaction of blended learning course.

In addition, examining the factors that affecting satisfaction of LMS is fundamental for its continuous use. The success of LMS, as for any information system can be evaluated in terms of students' satisfaction. Consequently, this study also seeks to examine the critical factors affecting the students' satisfaction of LMS usage based on the conceptual framework adapted from information system (IS) success model (DeLone \& McLean, 1992; 2003). Through literature review, several critical factors have been identified involving Computer Anxiety, Technology Experiences, Instructor Attitude, Classmates Attitude, Course Quality, Management Support, System Quality, and Information Quality.

\section{Research Model (Students' Satisfaction of LMS)}

As previously mentioned, this study examines the crucial factors for LMS satisfaction in a blended learning from the students' perspective. These factors - identified through literature review - are students' Computer Anxiety, Technology Experiences, Instructor Attitude, Classmates Attitude, Course Quality, Management Support, System Quality, and Information Quality. The satisfaction of blended learning is assessed according to user satisfaction factor as suggested by DeLone and McLean (1992; 2003). Fig. 1 illustrates the research model.

\subsection{Students' Computer Anxiety}

Computer anxiety is defined as the individuals' feeling of fear when using computers (Simonson et al., 1987). Several empirical studies have shown that computer anxiety significantly affects the student' satisfaction of e-learning system (Sun et al., 2008).

\subsection{Technology Experiences}

Students' technology experience has a major effect on learning processes and consequently, learning outcomes (Wan \& Fang, 2006).

\subsection{Instructors' Attitude}

The instructor's attitude toward LMS is essential to students' perception, use, and satisfaction of technology (LMS) and learning outcomes (Al-Busaidi, 2012).

\subsection{Classmates Attitude}

The attitude of classmates is significant on each student's involvement, attitude, and cognitive engagement toward the technology in an online learning environment (Webster \& Hackley, 1997).

\subsection{Course Quality}

The quality of LMS-mediated coursework is another critical determinant of the students' satisfaction of LMS in blended learning (Al-Busaidi, 2012). Thus, a well-designed course helps the students to improve their satisfaction with the LMS.

\subsection{Management Support}


Senior managers' support is a very important factor for students to satisfy and use LMS. Thus, senior managers must plainly define the goals of LMS usage for the university curriculum to motivate its students to use the system (Sumner \& Hostetler, 1999).

\subsection{System Quality}

System quality is a crucial factor of students' satisfaction of technology, including LMS. The common measures for system quality include usability, responsiveness, reliability, availability, flexibility, accessibility and adaptability (Delone \& Mclean, 2004).

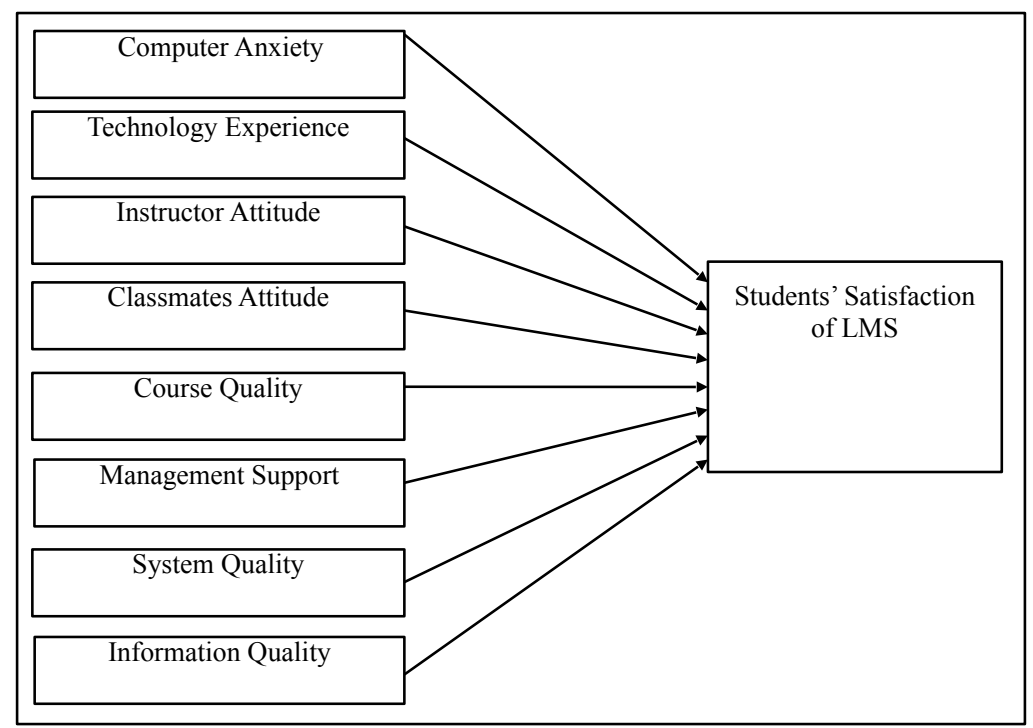

Fig.1: Research mode of the study

\subsection{Information Quality}

Information quality plays a key role in the use of an information system and user satisfaction (DeLone $\&$ McLean, 1992). Roca et al., (2006) measured information quality by indicators regarding sufficiency, clarity, relevance, accuracy, timeliness, and format.

\subsection{Student Satisfaction}

Students' satisfaction indicates the happiness and the agreement of system use. It is a measure of the success of an information system (DeLone \& McLean, 1992). Students' satisfaction is used as an important index of whether or not they would continue to take a learning system (Arbaugh, 2002).

\section{Methodology}

A quantitative research approach was used in this study. This study employed a survey method to investigate the level of students' satisfaction of LMS usage. Moreover, it attempts to identify the factors that affect their satisfaction on LMS usage. The descriptive statistics was used to identify the level of students' satisfaction toward LMS. Meanwhile, the inferential approach was used to determine the critical factors that influence the satisfaction toward LMS in the blended learning environment.

The participants in this study were undergraduate students from the public university in Yemen. A total of 174 students participated in this study, involving 94 male (54\%) and 80 female participants $(46 \%)$.

The data were collected through an online questionnaire. The questionnaire was developed based on existing, verified, and tested instruments to ensure the content validity. A five-point Likert scale (1 $=$ strongly disagree; $2=$ disagree; $3=$ Not Sure; $4=$ agree, and $5=$ strongly agree) was used for all the items in the questionnaire.

\section{Data Analysis and Results}

The reliability of the questionnaire was measured by Cronbach's alpha coefficient. Table 1 displays the Cronbach's alpha values for all the variables in the instruments with the numbers of the items. As shown in Table 1, all the constructs of the questionnaire exhibit a high value of the reliability as evidenced by their Cronbach's alpha (Cronbach, 1951). Therefore, it was concluded that the scale item enjoy an acceptable level of reliability. 
The Turkish Online Journal of Design, Art and Communication - TOJDAC

ISSN: 2146-5193, September 2018 Special Edition, p.1147-1156

Table 1: Reliability test

\begin{tabular}{l|c|c}
\hline \multicolumn{1}{c|}{ Construct } & $\begin{array}{c}\text { No of } \\
\text { Items }\end{array}$ & $\begin{array}{c}\text { Cronbach's } \\
\text { Alpha (a) }\end{array}$ \\
\hline Student Satisfaction & 5 & 0.921 \\
\hline Computer Anxiety & 5 & 0.907 \\
\hline Technology Experience & 4 & 0.905 \\
\hline Instructor Attitude & 3 & 0.857 \\
\hline Course Quality & 2 & 0.804 \\
\hline Management Support & 3 & 0.877 \\
\hline System Quality & 5 & 0.859 \\
\hline Information Quality & 5 & 0.919 \\
\hline
\end{tabular}

The level of participants' satisfaction has been identified by the following equation which was adapted from Landell (1997) and also applied by several authors (Wimolmas, 2013).

Interval Width = maximum point - minimum point $\backslash$ number of levels. Interval Width $=5-1 \backslash 3=1.33$

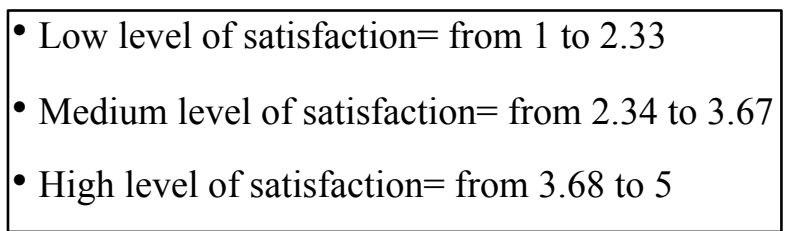

The highest score indicates the high level of satisfaction by the participants toward LMS; while the lowest score indicates the low level of satisfaction by them toward LMS.

The results indicated that the participants had a high level of satisfaction for LMS usage in a blended learning with a mean score of 3.93 (SD: 0.907). In general, Table 2 explains the overall mean score of each item of this satisfaction factor. Overall, the decision of using the e-learning system (item 3) recorded the highest mean score (4.05) followed by the pleasure of experiences in using the e-learning system (item 2) with high mean score (3.99). Then, their satisfaction in participating (item 5), system effectiveness (item 1) and interacting (item 4) in e-learning system recorded high mean scores with the values of 3.95, 3.84 and 3.82 respectively. In other words, the students were satisfied with all advantages provided by the e-learning system. All the means scores for the items in this factor were in the range of 3.82 to 4.05 .

Table 2: Means and standard deviations

\begin{tabular}{l|l|l}
\hline \multicolumn{1}{c|}{ Student Satisfaction } & Mean & SD \\
\hline 1. I am satisfied with the effectiveness of an e - learning system & 3.84 & 1.119 \\
\hline 2. I am pleased with my experience of using the e-learning system. & 3.99 & 1.026 \\
\hline 3. My decision to use the e-learning system was a wise one. & 4.05 & .975 \\
\hline 4. I am satisfied with the quality of interaction between all involved parties. & 3.82 & 1.003 \\
\hline 5. I am satisfied with my participation in the class. & 3.95 & 1.077 \\
\hline Total Mean & 3.929 & 0.907 \\
\hline
\end{tabular}


A multiple regression has been run to see if the eight critical LMS factors affect the student's satisfaction in the blended learning environment.

Table 3: Model summary

\begin{tabular}{c|c|c|c|c}
\hline Model & R & R Square & $\begin{array}{c}\text { Adjusted R } \\
\text { Square }\end{array}$ & $\begin{array}{c}\text { Std. Error of } \\
\text { the Estimate }\end{array}$ \\
\hline 1 & $0.738 \mathrm{a}$ & 0.545 & 0.543 & 0.61354 \\
\hline 2 & $0.789 \mathrm{~b}$ & 0.622 & 0.617 & 0.56111 \\
\hline 3 & $0.816 \mathrm{c}$ & 0.666 & 0.660 & 0.52875 \\
\hline 4 & $0.835 \mathrm{~d}$ & 0.698 & 0.691 & 0.50463 \\
\hline 5 & $0.841 \mathrm{e}$ & 0.707 & 0.698 & 0.49814 \\
\hline
\end{tabular}

a. Predictors: (Constant), System Quality

b. Predictors: (Constant), System Quality, Instructor Attitude

c. Predictors: (Constant), System Quality, Instructor Attitude, Course Quality

d. Predictors: (Constant), System Quality, Instructor Attitude, Course Quality, Management Support

e. Predictors: (Constant), System Quality, Instructor Attitude, Course Quality, Management Support, Classmate Attitude

In this study, the LMS satisfaction factors (Computer anxiety, Technology Experiences, Instructor Attitude, Classmates Attitude, Course Quality, Management Support, System Quality, and Information Quality) were treated as the 'independent' or predictor variables and student satisfaction was treated as 'dependent' or criterion variable. The results of the stepwise regression are showed in Table 3, Table 4, and Table 5.

Table 3 displays the $\mathrm{R}$ value, $\mathrm{R}$ square values, adjusted $\mathrm{R}$ Square values, and Std. Error of the Estimates for each of the of the five models. The adjusted $\mathrm{R}^{2}=0.698$ was statistically significant. In other words, about $69.8 \%$ of the variances in the student satisfaction of LMS usage can be explained by the linear combination of System Quality, Instructor Attitude, Course Quality, Management Support, and Classmate Attitude in a blended learning environment. It indicates that $30.2 \%$ of the student satisfaction factor was explained by something other than the five factors.

Table 4: ANOVA

\begin{tabular}{|c|c|c|c|c|c|c|}
\hline & Model & $\begin{array}{l}\text { Sum of } \\
\text { Squares }\end{array}$ & df & $\begin{array}{l}\text { Mean } \\
\text { Square }\end{array}$ & $\mathbf{F}$ & Sig. \\
\hline 1 & Regression & 77.639 & 1 & 77.639 & 206.253 & $.000 \mathrm{~b}$ \\
\hline & Residual & 64.745 & 172 & .376 & & \\
\hline & Total & 142.385 & 173 & & & \\
\hline 2 & Regression & 88.547 & 2 & 44.273 & 140.622 & $.000 \mathrm{c}$ \\
\hline
\end{tabular}


The Turkish Online Journal of Design, Art and Communication - TOJDAC

ISSN: 2146-5193, September 2018 Special Edition, p.1147-1156

\begin{tabular}{|c|c|c|c|c|c|c|}
\hline & Residual & 53.838 & 171 & .315 & & \\
\hline & Total & 142.385 & 173 & & & \\
\hline \multirow[t]{3}{*}{3} & Regression & 94.856 & 3 & 31.619 & 113.093 & $.000 \mathrm{~d}$ \\
\hline & Residual & 47.529 & 170 & .280 & & \\
\hline & Total & 142.385 & 173 & & & \\
\hline \multirow[t]{3}{*}{4} & Regression & 99.349 & 4 & 24.837 & 97.536 & $.000 \mathrm{e}$ \\
\hline & Residual & 43.035 & 169 & .255 & & \\
\hline & Total & 142.385 & 173 & & & \\
\hline \multirow[t]{3}{*}{5} & Regression & 100.696 & 5 & 20.139 & 81.159 & $.000 \mathrm{f}$ \\
\hline & Residual & 41.688 & 168 & .248 & & \\
\hline & Total & 142.385 & 173 & & & \\
\hline
\end{tabular}

Table 4 displays the test of significance of the model using an ANOVA. The test was significant at 0.05 level of significance, $\left[\mathrm{F}(5,168)=81.159, \mathrm{p}<0.05, \mathrm{R}^{2} \mathrm{adj}=0.698\right]$. As a result, at least one predictor variable (System Quality, Instructor Attitude, Course Quality, Management Support, and Classmate Attitude) is a statistically important predictor of students' satisfaction of LMS usage in a blended learning.

Table 5: Coefficients

\begin{tabular}{|c|c|c|c|c|c|c|}
\hline \multirow{2}{*}{\multicolumn{2}{|c|}{ Model }} & \multicolumn{2}{|c|}{ Unstandardized Coefficients } & \multirow{2}{*}{$\begin{array}{c}\begin{array}{c}\text { Standardize } \\
\text { d } \\
\text { Coefficients }\end{array} \\
\text { Beta }\end{array}$} & \multirow[b]{2}{*}{$\mathbf{t}$} & \multirow[b]{2}{*}{ Sig. } \\
\hline & & $B$ & Std. Error & & & \\
\hline \multirow[t]{6}{*}{5} & (Constant) & -.191 & .215 & & -.889 & .375 \\
\hline & System Quality & .334 & .071 & .302 & 4.709 & .000 \\
\hline & Instructor Attitude & .219 & .050 & .223 & 4.401 & .000 \\
\hline & Course Quality & .258 & .056 & .276 & 4.624 & .000 \\
\hline & Management Support & .171 & .046 & .187 & 3.748 & .000 \\
\hline & Classmate Attitude & .112 & .048 & . 109 & 2.330 & .021 \\
\hline
\end{tabular}


a. Dependent Variable: Student Satisfaction

Table 5 lists the regression coefficients of the five regression models constructed via stepwise regression method. There are five independent variables emerged as positive predictors to student satisfaction: System Quality, Instructor Attitude, Course Quality, Management Support, and Classmate Attitude.

The student satisfaction was primarily determined in a positive manner by System Quality $[\boldsymbol{\beta}=$ $0.302, \mathrm{p}<0.05]$, Instructor Attitude $[\boldsymbol{\beta}=0.223, \mathrm{p}<0.05]$, Course Quality $[\boldsymbol{\beta}=0.276, \mathrm{p}<0.05]$, Management Support $[\boldsymbol{\beta}=0.187, \mathrm{p}<0.05]$, and Classmate Attitude $[\boldsymbol{\beta}=0.109, \mathrm{p}<0.05]$. Apparently, System Quality $(\boldsymbol{\beta}=0.302)$ was the best predictor in affecting their satisfaction of LMS usage in a blended learning environment. The findings showed that five factors were statistically significant $(p<0.05)$ in influencing the student satisfaction of LMS usage.

The remaining factors, namely Computer Anxiety, Technology Experiences, and Information Quality, did not contribute significantly towards affecting the dependent variable (Student Satisfaction). These factors were not important in the satisfaction of blended learning by the respondents. Thus, these factors were not retained in the regression.

\section{Discussion}

The results of the study revealed that the students have a high level of satisfaction for LMS usage in a blended learning. This result supports the research by Giannousi et al., (2009) who found that perceived students' satisfaction was higher than the average, indicating that they are very satisfied with the overall learning experience. The students' decision on the use of e-learning achieved the highest level of satisfaction in a blended learning. This is maybe due to the fact that majority of them have experience of using computers which in return have influenced their decision to use or continue with the course in a blended learning. Consequently, it has affected their level of satisfaction. This finding was supported by that of Bolliger and Wasilik (2009). Interestingly, the students report greater satisfaction with using e-learning system as they become more experienced with online courses. Similar results can be seen in the study of Malik (2010) wherein he cited that knowledge of using computers significantly affect the level of students' satisfaction.

In addition, the results revealed that high levels of satisfaction towards e-learning might be due to the high quality of interaction between all involved parties. This point of view is supported by the findings of Cheng (2012). Moreover, the study reported that the students were satisfied with the advantages provided by the e-learning system in terms of their participation and system effectiveness. These features are considered as important factors which influence their level of satisfaction in such environment. It should be noted that in the literature, common factors earlier used to determine student's satisfaction have been quality, interaction, and effectiveness (Liaw, 2008). This basically supports the present study by confirming those variables identified as good factors to affect their level of satisfaction.

The stepwise multiple regression analysis was used to investigate the factors that affect the students' satisfaction. The results revealed that the System Quality, Instructor Attitude, Course Quality, Management Support, and Classmate Attitude are the crucial factors affecting those students' satisfaction.

The results proved that there is a highly positive relationship between system quality of the LMS and student satisfaction. The finding discovered that the user interface is a space where a high level of interaction happens; a user-friendly, well-designed, interface becomes one of the most crucial factors in identifying the students' satisfaction when using the LMS. This is in line with many Information System-related studies (Al-Busaidi, 2012; Cheng, 2012; Ghazal et al., 2017).

The instructor attitude toward e-learning system has a positive significant effect on the student's satisfaction of LMS usage. Attitude toward using network technology and computer and in delivering training and instruction will affect students' attitudes and impact their satisfaction. These results are consistent with earlier research (Cheng, 2012; Lee, 2010). 
The classmate attitude toward e-learning system has a positive significant effect on the student's satisfaction of LMS usage. Their classmates' attitude toward using computer and network technology in the online course has affected students' attitudes and affect their satisfaction. These results are consistent with earlier research (e.g.: Cheng, 2012; Lee, 2010).

The course quality is also a strong indicator of student satisfaction. It includes overall interactive discussion arrangements, course design, teaching materials, etc. For higher satisfaction, the course schedule, discussion arrangement and types, and course materials must be properly prepared, and the e-learning expertise and technical assistance must be in place. Thus, the quality of online courses was identified as an important factor in student satisfaction. These findings are consistent with those found in previous studies (example: Arbaugh, 2002; Sun et al., 2008).

The finding also indicated that the management supports is also a strong indicator of the student satisfaction of LMS usage. In other words, senior managers' support is important for the students' satisfaction in LMS. This finding is supported with the study from Lee (2010).

However, three other factors - computer anxiety, technology experiences, and information quality did not influence the students' satisfaction. This is maybe due to the fact that some students are highly experienced internet users, but they do not have much e-learning experience. Thus, a number of students may struggle with acquiring the crucial technical skills to function well in a blended learning environment. In the context of Yemen, every undergraduate student is required to take at least one introductory computer course to improve computing skills and computer literacy. Computer courses are even offered in the secondary school curriculum, and therefore, computer illiteracy no longer exists among these university students. This finding is supported by Liaw (2008). In addition, Liaw indicated that although students believe that e-learning system is a useful assisted learning tool, they are concerned with the information quality, especially interactivity.

\section{Conclusion}

This study offered insights for universities to enhance LMS implementation and improve students' satisfaction. The study concludes that a perception of unsatisfactory may led to obstruct the students' motivation to continue learning and participating in a blended learning environment.

\section{Acknowledgment}

Authors would like to thank Universiti Sains Malaysia (USM) for the financial support.

\section{References}

Ahmed, H. M. S. (2010). Hybrid E-Learning Acceptance Model: Learner Perceptions. Decision Sciences Journal of Innovative Education, 8(2), 313-346.

Akkoyunlu, B., \& Soylu, M. Y. (2008). A study of student's perceptions in a blended learning environment based on different learning styles. Journal of Educational Technology \& Society, 11(1), 183-193.

Al-Busaidi, K. A. (2012). Learners' perspective on critical factors to LMS success in blended learning: An empirical investigation. Communications of the Association for Information Systems, 30(2), 11-34.

Aldowah, H., Ghazal, S., \& Muniandy, B. (2015). Issues and Challenges of Using E-Learning in a Yemeni Public University. Indian Journal of Science and Technology, 8(32).

Andersen, J. C. (2013). Learner Satisfaction in Online Learning: An Analysis of the Perceived Impact of Learner-Social Media and Learner-Instructor Interaction.

Angelino, L. M., Williams, F. K., \& Natvig, D. (2007). Strategies to Engage Online Students and Reduce Attrition Rates. Journal of Educators Online, 4(2), $n 2$.

Arbaugh, J. B. (2002). Managing the on-line classroom: A study of technological and behavioral characteristics of web-based MBA courses. The Journal of High Technology Management Research, 13(2), 203-223. 
Bauk, S., Šćepanović, S., \& Kopp, M. (2014). Estimating Students' Satisfaction with Web Based Learning System in Blended Learning Environment. Education Research International, 2014.

Bolliger, D. U., \& Wasilik, O. (2009). Factors influencing faculty satisfaction with online teaching and learning in higher education. Distance Education, 30(1), 103-116.

Chang, V., \& Fisher, D. (2003). The validation and application of a new learning environment instrument for online learning in higher education. Technology-rich learning environments: A future perspective, 1-18.

Cheng. (2012). Effects of quality antecedents on e-learning acceptance. Internet Research, 22(3), 361-390.

Cronbach, L. J. (1951). Coefficient alpha and the internal structure of tests. psychometrika, 16(3), 297-334.

DeLone, W. H., \& McLean, E. R. (1992). Information systems success: The quest for the dependent variable. Information Systems Research, 3(1), 60-95.

Delone, W. H., \& McLean, E. R. (2003). The DeLone and McLean model of information systems success: a ten-year update. Journal of management information systems, 19(4), 9-30.

Delone, W. H., \& Mclean, E. R. (2004). Measuring e-commerce success: Applying the DeLone \& McLean information systems success model. International Journal of Electronic Commerce, 9(1), 31-47.

Ghazal, S., Aldowah, H., \& Umar, I. (2017). Critical Factors to Learning Management System Acceptance and Satisfaction in a Blended Learning Environment. Paper presented at the International Conference of Reliable Information and Communication Technology.

Giannousi, M., Vernadakis, N., Derri, V., Michalopoulos, M., \& Kioumourtzoglou, E. (2009). Students' satisfaction from blended learning instruction. Paper presented at the TCC Worldwide Online Conference.

Graham, C. R. (2006). Blended learning systems. CJ Bonk \& CR Graham, The handbook of blended learning: Global perspectives, local designs. Pfeiffer.

Jenkins, M., Browne, T., Walker, R., \& Hewitt, R. (2011). The development of technology enhanced learning: findings from a 2008 survey of UK higher education institutions. Interactive Learning Environments, 19(5), 447-465.

Landell, K. (1997). Management by menu. London: Wilay and Sms Inc.

Lee, J.-W. (2010). Online support service quality, online learning acceptance, and student satisfaction. The internet and higher education, 13(4), 277-283.

Lee, S. J., Srinivasan, S., Trail, T., Lewis, D., \& Lopez, S. (2011). Examining the relationship among student perception of support, course satisfaction, and learning outcomes in online learning. The internet and higher education, 14(3), 158-163.

Liaw, S.-S. (2008). Investigating students' perceived satisfaction, behavioral intention, and effectiveness of e-learning: A case study of the Blackboard system. Computers \& education, 51(2), 864-873.

Malik, M. W. (2010). Factor Effecting Learner's Satisfaction Towards E-Learning: A Conceptual Framework. OIDA International Journal of Sustainable Development, 2(3), 77-82.

Roca, J. C., Chiu, C.-M., \& Martínez, F. J. (2006). Understanding e-learning continuance intention: An extension of the Technology Acceptance Model. International Journal of human-computer studies, 64(8), 683-696.

Simonson, M. R., Maurer, M., Montag-Torardi, M., \& Whitaker, M. (1987). Development of a standardized test of computer literacy and a computer anxiety index. Journal of educational computing research, 3(2), 231-247.

So, H.-J., \& Brush, T. A. (2008). Student perceptions of collaborative learning, social presence and satisfaction in a blended learning environment: Relationships and critical factors. Computers \& education, 51(1), 318-336.

Sumner, M., \& Hostetler, D. (1999). Factors influencing the adoption of technology in teaching. AMCIS 1999 Proceedings, 332.

Sun, P.-C., Tsai, R. J., Finger, G., Chen, Y.-Y., \& Yeh, D. (2008). What drives a successful e-Learning? An empirical investigation of the critical factors influencing learner satisfaction. Computers \& education, 50(4), 1183-1202.

Wan, Z., \& Fang, Y. (2006). The role of information technology in technology-mediated learning: A review of the past for the future. AMCIS 2006 Proceedings, 253. 
The Turkish Online Journal of Design, Art and Communication - TOJDAC

ISSN: 2146-5193, September 2018 Special Edition, p.1147-1156

Webster, J., \& Hackley, P. (1997). Teaching effectiveness in technology-mediated distance learning. Academy of management journal, 40(6), 1282-1309.

Wimolmas, R. (2013). A survey study of motivation in English language learning of first year undergraduate students at Sirindhorn International Institute of Technology (SIIT), Thammasat University: Language Institute, Thammasat University. 